\title{
Antioxidant Properties and Phytochemical Contents of Garcinia schomburgkiana Pierre.
}

\author{
Imron Meechai ${ }^{1,2}$, Worrapong Phupong ${ }^{1,2, *}$, Warangkana Chunglok ${ }^{3}$, Puttinan Meepowpan ${ }^{4}$ \\ ${ }^{1}$ School of Science, Walailak University, Tha Sala, Nakhon Si Thammarat, 80161, Thailand. ${ }^{2}$ The Research Unit of Natural Product Utilization, Walailak \\ University, Nakhon Si Thammarat, 80161, Thailand. ${ }^{3}$ School of Allied Health Sciences and Public Health, Walailak University, Tha Sala, Nakhon Si \\ Thammarat, 80161, Thailand. ${ }^{4}$ Department of Chemistry, Faculty of Science, Chiang Mai University, Chiang Mai, 50200, Thailand.
}

\author{
ARTICLE INFO \\ Article history: \\ Received on: 26/01/2016 \\ Revised on: 17/03/2016 \\ Accepted on: 11/04/2016 \\ Available online: 28/06/2016 \\ Key words: \\ Garcinia schomburgkiana; \\ antioxidant activity; \\ phytochemical; \\ fatty acid derivative; GC-MS.
}

\begin{abstract}
This study was conducted to determine the phytochemical contents and radical scavenging activities of twelve Garcinia schomburgkiana extracts from the leaves, roots, twigs and branches. Among all extracts, the root (RA) and branch (BA) acetone extract revealed high phenolic (427.83 \pm 4.84 and $390.15 \pm 7.89 \mathrm{mg}$ GAE/g extract), flavonoid $(626.32 \pm 59.97$ and $414.49 \pm 15.99 \mathrm{mg} \mathrm{QE} / \mathrm{g}$ extract) and xanthone $(625.80 \pm 3.78$ and $615.07 \pm 9.97 \mathrm{mg}$ AME/g extract) contents and possessed greater antioxidant capacities and radical scavenging activities than the standard vitamin $\mathrm{C}$ and Trolox. Our results reveal that G. schomburgkiana were potential natural sources of antioxidant with high amount of phenolics, flavonoids xanthones and beneficial fatty acid derivatives.
\end{abstract}

\section{INTRODUCTION}

Theoretically, the reactive oxygen species (ROS) and reactive nitrogen species (RNS) such as, superoxide, hydroxyl radical, peroxyl radical and nitric oxide, are pro-oxidant and oxidant species from the nutrient metabolic processes (LimónPacheco and Gonsebatt, 2009; Limón-Pacheco et al., 2006). They play an important role for biochemical processes at the low concentrations (Ahmed, 2005; Khansari et al., 2009; Ratnam et al., 2006). In one sense, the overproduction of the ROS and RNS species, from internal and external excitation such as, irradiation, chemical, pollution and stress (Poljšak and Fink, 2014; Sen et al., 2010), is believed to be a cause of most human diseases, like cancer, chronic inflammation, aging, Parkinson's disease, Alzheimer's disease and hypertension (Ratnam et al., 2006; Limón-Pacheco and Gonsebatt, 2009; Khansari et al., 2009). Nowadays, antioxidants are scientifically attractive since they

\footnotetext{
* Corresponding Author

Worrapong Phupong, School of Science, Walailak University, Tha Sala, Nakhon Si Thammarat, 80161, Thailand. Email: worrapong@gmail.com
}

can prevent cell destructions caused by the action of free radicals (Poljšak and Fink, 2014; Sen et al., 2010). Numerous scientists, therefore, attempt to search for the promising compounds from both natural resources and synthetics. Compounds are designed, synthesized and evaluated for their antioxidation properties. However, synthetic antioxidants are claimed to be industrially high-priced and toxic to the body (Tavasalkar et al., 2012). Natural sources such as vegetables, fruits and medicinal plants which are relatively cheaper and render fewer side effects (Sen et al., 2010), are of interest for the investigation of new antioxidants, like flavonoids, stilbenes, xanthones and phenolic acid (Leopoldini et al., 2011; Pedraza-Chaverri et al., 2008). Reportedly, plants in the Guttiferae family (Clusiaceae) such as, Garcinia hombroniana, $G$. mangostana, G. brasiliensis, G. lateriflora var. javanica, $G$. combogia and $G$. virgate, are known sources of a variety of biological active natural compounds, e.g., xanthone, terpenoid, benzophenone and flavonoid (Elya et al., 2012; Gontijo et al., 2012; Jung et al., 2006; Kosema et al., 2004; Merza et al., 2004; Nargis et al., 2013; Pedraza-Chaverri et al., 2008; Subhashini et al., 2011; Yu et al., 2007). 
For instance, G. mangostana or magosteen, also recognized by the epithet "the queen of fruit", not only is a popular fruit, but also can be used as traditional medicines for diarrhea, infected wound, inflammation, chronic ulcer and as antioxidant, antitumor, anti-allergic, anti-inflammatory, antibacterial, antifungal and antiviral herbs (Pedraza-Chaverri et al., 2008).

Currently, the consumption of mangosteen juice and mangosteen capsules as the dietary supplements dramatically increase in the market for health care people (Gutierrez-Orozco and Failla, 2013; Tang et al., 2009).

Garcinia schomburgkiana, locally known as Ma-dan, is another interesting natural source of antioxidative compounds. This plant is widely distributed in the central and southern areas of evergreen forests in Thailand. Its sour-tasting fruit, besides being consumed fresh and fermented by local people, is also traditionally used for the treatment of laxation, cough, and diabetes (Lim, 2012).

Typically, the fruit methanol extract has been reported to have high total phenolic content and possess antioxidant activity and ferric reducing ability (Wetwitayaklung et al., 2012; Nanasombat et al., 2012). In addition, several chemical constituents from Ma-dan extracts revealed the potent cytotoxic activities against various cancer cell lines (Häfner\&Frahm, 1993; Wetwitayaklung et al., 2012; Nanasombat et al., 2012; Fun et al., 2006; Vo et al., 2012; Mungmee et al., 2013).

To the best of our knowledge, there have been a few reports about Ma-dan on its total phytochemical content and antioxidant activity (Wetwitayaklung et al., 2012; Nanasombat et al., 2012). To supplement the current medical data with a new potential source of antioxidants, we report herein the extraction procedures, the antioxidant activities of the Ma-dan extracts against all of these radicals (DPPH, ABTS, nitric oxide and hydroxyl radicals), their phytochemical contents (total phenolic contents, total flavonoid contents, total xanthone contents) and the GC-MS analysis.

\section{MATERIALS AND METHODS}

\section{Chemicals and reagents}

Aluminium chloride hexahydrate, ferrous sulphateheptahydrate, Folin-Ciocalteu's phenol reagent, sodium carbonate, sodium nitroprussidedihydrate and $N$-1-naphthyl ethylene diaminedihydrochloride were purchased from LobaChemie Pvt. Ltd. (India), ascorbic acid (Vitamin C) and sulphanilamide from Carlo Erba Reagents S.r.l. (Italy), potassium persulphate and salicylic acid from Ajax Finechem, Thermo Fisher Scientific Pty. Ltd. (Australia), 1,1-diphenyl-2-picrylhydrazyl (DPPH), 2,2'-azinobis(3-ethylbenzothiazoline-6-sulfonic acid)diammonium salt (ABTS), 6-hydroxy-2,5,7,8tetramethylchroman-2-carboxylic acid (Trolox), quercetin, $\alpha$ mangostin and dimethylsulfoxide (DMSO) from Sigma-Aldrich Pte. Ltd. (products from Germany, Denmark, India, China and France, respectively), gallic acid from Merck KGaA (Germany) and AR grade methanol from Fisher Chemicals, Fisher Scientific
UK Ltd. (United Kingdom). The commercial grade solvents were used for extraction.

\section{Plant Materials and Extraction Procedure}

The leaves, roots, twigs and branches of Garcinia schomburgkiana were collected from Trang province, Southern Thailand in August 2012. The samples were dried at room temperature for 5-7 days and cut into small size. Each part of the collected sample was macerated in triplicate with dichloromethane at room temperature for 3 days. The residue was subsequently extracted with acetone and finally with methanol. The extracts were then filtered and evaporated under reduced pressure to obtain 12 crude extracts (Table 1 ).

Table 1: Abbreviation of Ma-dan extracts.

\begin{tabular}{lcc}
\hline Parts & Solvent extractions & Abbreviations \\
\hline \multirow{3}{*}{ Leaves } & Dichloromethane & LD \\
& Acetone & LA \\
& Methanol & LM \\
\hline \multirow{3}{*}{ Roots } & Dichloromethane & RD \\
& Acetone & RA \\
& Methanol & RM \\
Twigs & Dichloromethane & TwD \\
& Acetone & TwA \\
& Methanol & TwM \\
Branches & Dichloromethane & BD \\
& Acetone & BA \\
& Methanol & BM
\end{tabular}

\section{Determination of Total Phenolic Content (TPC)}

Folin-Ciocalteu's method with slight modification was applied to determine the total phenolic content (Panyathepa et al., 2013). In a 96 -well plate, $12.5 \mu \mathrm{L}$ of extract solutions $(250 \mu \mathrm{g} / \mathrm{mL}$ in DMSO) or standard gallic acid solutions were added, followed by $50 \mu \mathrm{L}$ of DI water and $12.5 \mu \mathrm{L}$ of Folin-Ciocalteu $(50 \% \mathrm{v} / \mathrm{vin}$ DI water). After $10 \mathrm{~min}, 125 \mu \mathrm{L}$ of $7 \% \mathrm{Na}_{2} \mathrm{CO}_{3}$ and $100 \mu \mathrm{L}$ of DI water were added. The mixture was allowed to stand for $15 \mathrm{~min}$ at $45{ }^{\circ} \mathrm{C}$ and the absorbance was determined at $765 \mathrm{~nm}$. Total phenolic content was calculated from gallic acid standard curve with linear relation of $r^{2}=0.997$. Data were expressed as $\mathrm{mg}$ of gallic equivalent (GAE) per $1 \mathrm{~g}$ of extract.

\section{Determination of Total Flavonoid Content (TFC)}

In order to investigate the total flavonoid content, a colorimetric method was applied (Zongo et al., 2010). In a 96-well plate, $100 \mu \mathrm{L}$ of the extracts $(100 \mu \mathrm{g} / \mathrm{mL}$ in DMSO) or standard quercetin solutions and $100 \mu \mathrm{L}$ of $2 \% \mathrm{AlCl}_{3}$ in methanol were added and mixed thoroughly. The reaction mixture was kept at room temperature for $15 \mathrm{~min}$ and the absorbance was recorded at $435 \mathrm{~nm}$. The total flavonoid content was calculated using quercetin standard curve with linear relation of $r^{2}=0.999$. Data were expressed as mg quercetin equivalent (QE) per $1 \mathrm{~g}$ of extract.

\section{Determination of Total Xanthone Content (TXC)}

The total xanthone content was evaluated with the use of UV-visible spectrophotometric method (Aisha et al., 2013; Pothitirat and Gritsanapan., 2008). With a microplate reader, the 
absorbance was determined at $320 \mathrm{~nm}$. The total xanthone content was expressed as mg of the $\alpha$-mangostin equivalent (AME) per $1 \mathrm{~g}$ of extract using $\alpha$-mangostin standard curve with linear relation of $r^{2}=0.999$.

\section{Gas Chromatography-Mass Spectrometry (GC-MS) Analysis}

In order to perform the GC-MS analysis, a Trace GC Ultra gas chromatography coupled with ISQ mass spectrometer (Thermo Scientific Inc., USA) was applied. A TR-5MS capillary column (30 m x $0.25 \mathrm{~mm}$ I.D., $0.25 \mathrm{~mm}$ film thickness) was employed to separate the volatile and semi-volatile compounds. In the gas chromatography, $1 \mu \mathrm{L}$ of the extracts (dissolved in acetone) was injected in splitless mode with the injector temperature at $250{ }^{\circ} \mathrm{C}$. The $\mathrm{GC}$ oven operating conditions were 50 (6 min) to $280{ }^{\circ} \mathrm{C}$ at $5{ }^{\circ} \mathrm{C} / \mathrm{min}$ and $280{ }^{\circ} \mathrm{C}$ (5 min). Helium was used as carrier gas with constant flow mode at $1.0 \mathrm{~mL} / \mathrm{min}$. The transfer line was set at $250{ }^{\circ} \mathrm{C}$ and ion source temperature was set to $230{ }^{\circ} \mathrm{C}$. GC-MS was operated in the $70 \mathrm{eV}$ electron ionization (EI) mode with a collected mass range of 35 to $500 \mathrm{amu}$. The components were identified by comparison with wiley 9 database.

\section{Antioxidant Capacity Assay}

The diphenyl-2-picrylhydrazyl (DPPH) radical scavenging assay was performed with a microplate reader (Zongo et al., 2010). In the reaction well, $100 \mu \mathrm{L}$ of the extracts $(250$ $\mu \mathrm{g} / \mathrm{mL}$ in DMSO) or standard solution was mixed with $100 \mu \mathrm{L}$ of the DPPH-radical $(100 \mu \mathrm{g} / \mathrm{mL}$ in methanol) and left to stand at room temperature for $15 \mathrm{~min}$ in the dark. The absorbance was measured at $517 \mathrm{~nm}$. Vitamin $\mathrm{C}$ was used as the standard. The percentage of DPPH-radical scavenging was calculated from the equation 1 and the antioxidant capacity of the extracts was expressed as vitamin $\mathrm{C}$ equivalent antioxidant capacity (VCEAC).

The 2,2'-azinobis(3-ethylbenzothiazoline-6-sulfonic acid) diammonium salt (ABTS) cation radical scavenging assay was performed with a slight modification ( $\operatorname{Re}$ et al., 1999). The working ABTS cation radical reagent was prepared by mixing ABTS and potassium persulfate $\left(\mathrm{K}_{2} \mathrm{~S}_{2} \mathrm{O}_{8}\right)$ in DI water to obtain the final concentration of $7 \mathrm{mM}$ and $2.45 \mathrm{mM}$, respectively. The mixture was stored in the dark at $4{ }^{\circ} \mathrm{C}$ for $12-16 \mathrm{~h}$. Before being used, this prepared reagent was diluted with DI water until its absorbance value reached $0.7 \pm 0.02$ at $734 \mathrm{~nm}$. To assess its free radical scavenging activity, $20 \mu \mathrm{L}$ of the extracts $(250 \mu \mathrm{g} / \mathrm{mL}$ in DMSO) or standard solution was mixed with $180 \mu \mathrm{L}$ of the working ABTS cation radical reagent. The absorbance was measured at $734 \mathrm{~nm}$ after $3 \mathrm{~min}$ incubation at room temperature. To calculate the percentage of ABTS cation radical scavenging, the equation 1 was applied. With the application of the Trolox standard curve, the antioxidant capacity of the extracts was expressed as Trolox Equivalent Antioxidant Capacity (TEAC).

$\%$ Radical scavenging activity $=\left[1-\left(\mathrm{A}_{\text {sample }} / \mathrm{A}_{\text {control }}\right)\right] \times 100(1)$

Where, $\mathrm{A}_{\text {sample }}$ : The absorbance of the extracts or standards mixed with DPPH or ABTS ${ }^{+}$.

$\mathrm{A}_{\text {control: }}$ The absorbance of the DMSO mixed with DPPH or $\mathrm{ABTS}^{+\cdot}$.

\section{Determination of Nitric Oxide Scavenging Activity}

The nitric oxide scavenging activity in which vitamin $\mathrm{C}$ and quercetin were used as the standards was spectrophotometrically performed at $577 \mathrm{~nm}$ (Harput et al., 2011; Ho et al., 2010). To a 96-well plate, $50 \mu \mathrm{L}$ of the extracts of varying concentrations ranging from 0 to $1,000 \mu \mathrm{g} / \mathrm{mL}$ and $50 \mu \mathrm{L}$ of $10 \mathrm{mM}$ sodium nitroprusside in phosphate buffer saline (PBS), $\mathrm{pH} 7.4$, were added. The reaction mixture was incubated at room temperature for $150 \mathrm{~min}$ under light condition, and $100 \mu \mathrm{L}$ of Griess reagent (1 \% sulfanilamide and $0.1 \% \quad \mathrm{~N}-(1-$ Naphthyl)ethylenediaminedihydrochloride in $\left.2.5 \% \mathrm{H}_{3} \mathrm{PO}_{4}\right)$ was then added. The absorbance was recorded after being left at room temperature for $10 \mathrm{~min}$. Equation 2 was used to calculate the percentage of NO-scavenging activity. The result was reported as a sufficient concentration to obtain $50 \%$ of a maximum nitric oxide scavenging capacity $\left(\mathrm{SC}_{50}\right)$.

$\%$ NO- scavenging activity $=\left[1-\left(\mathrm{A}_{\text {sample }}-\mathrm{A}_{\text {sample blank }} / \mathrm{A}_{\text {control }}-\mathrm{A}_{\text {control }}\right.\right.$ blank $)] \times 100(2)$

Where, $\left(\mathrm{A}_{\text {sample }}-\mathrm{A}_{\text {sample blank }}\right)$ : The difference in the absorbance of the extracts or standards, with or without sodium nitroprusside.

( $\left.\mathrm{A}_{\text {control }}-\mathrm{A}_{\text {control blank }}\right)$ : The difference in the absorbance of DMSO, with or without sodiumnitroprusside.

\section{Determination of Hydroxyl Radical Scavenging Assay}

A slightly modified method was used to determine the hydroxyl radical scavenging activity inwhich Trolox and gallic acid were used as the standards (Omwamba et al., 2013; Sudha et al., 2011). Into a 96-well plate, $90 \mu \mathrm{L}$ of the extracts (the concentrations ranging from 0 to $1,000 \mu \mathrm{g} / \mathrm{mL}), 45 \mu \mathrm{L}$ of $8 \mathrm{mM}$ $\mathrm{FeSO}_{4} \cdot 7 \mathrm{H}_{2} \mathrm{O}, 63 \mu \mathrm{L}$ of $5.7 \mathrm{mM}$ salicylic acid and $72 \mu \mathrm{L}$ of $6 \mathrm{mM}$ $\mathrm{H}_{2} \mathrm{O}_{2}$ were mixed and the absorbance was measured at $562 \mathrm{~nm}$ after a $30 \mathrm{~min}$ incubation at $37{ }^{\circ} \mathrm{C}$. Equation 3 was applied to calculate the percentage of the hydroxyl scavenging activity. The data was reported as a sufficient concentration to obtain $50 \%$ of the maximum hydroxyl radical scavenging capacity $\left(\mathrm{SC}_{50}\right)$.

$\% \mathrm{OH}$-scavenging activity $=\left[1-\left(\mathrm{A}_{\text {sample }}-\mathrm{A}_{\text {sample blank }} / \mathrm{A}_{\text {control- }}-\mathrm{A}_{\text {control }}\right.\right.$ blank)] x100(3)

Where, $\left(\mathrm{A}_{\text {sample }}-\mathrm{A}_{\text {sample blank }}\right)$ : The difference in the absorbance of the extracts or standards, with or without salicylic acid.

( $\left.\mathrm{A}_{\text {control }}-\mathrm{A}_{\text {control blank }}\right)$ : The difference in the absorbance of DMSO, with or without salicylic acid.

\section{Statistical Analysis}

All analyses were tested in triplicate and represented as the means \pm standard deviation (SD). The $t$-test method was used to differentiate the samples with a significance level of 0.05 ( $p<$ $0.05)$.

\section{RESULTS AND DISCUSSIONS}

According to the phytochemical determination, $G$. schomburgkiana was considered to be a vital source of phenolic, flavonoid and xanthone constituents. Table 2, displaying the values of antioxidant substances TPC, TFC and TXC of twelve $G$. schomburgkiana extracts, showed that the RA extract provided the 
highest amount of TPC, TFC and TXC with $427.83 \pm 4.84 \mathrm{mg}$ GAE/g extract, 626.32 $\pm 59.97 \mathrm{mg} \mathrm{QE} / \mathrm{g}$ extract and $625.80 \pm 3.78$ $\mathrm{mg} \mathrm{AME} / \mathrm{g}$ extract, respectively. In addition, the BA extract exhibited another minor source of TPC (390.15 $\pm 7.89 \mathrm{mg} \mathrm{GAE} / \mathrm{g}$ extract) and TFC (414.49 $\pm 15.99 \mathrm{mg} Q \mathrm{QE} / \mathrm{g}$ extract). TXC in BA extract was comparable to that in RA extract with the value of 615.07 $\pm 9.97 \mathrm{mg} \mathrm{AME} / \mathrm{g}$ extract. For the other extracts, ascending order of TPC was TwM $>$ TwA $>$ BM $>$ RM, RD,TwD> BD> LM and $\mathrm{LD}$, the order of TFC was RD,TwA, RM >TwM, BM TwD> $\mathrm{LD}>\mathrm{LA}>\mathrm{BD}$, and the order of TXC was $\mathrm{LD}>\mathrm{TwA}>\mathrm{TwD}>\mathrm{RD}$ $>\mathrm{BM}, \mathrm{BD}, \mathrm{RM}>\mathrm{LM}>\mathrm{TwM}$. The LA extract had the lowest amount of TPC and TXC, and the least value of TFC was LM.

The levels of antioxidant capacity, investigated by the $\mathrm{DPPH}, \mathrm{ABTS}^{+}$, nitric oxide and hydroxyl radical scavenging assay were also reported in Table 2 . In this study, The RA and BA extracts provided the values of VCEAC and TEAC better than the other extracts. The BA extract which had lesser phytochemical contents than RA extract displayed the highest DPPH and ABTS ${ }^{+}$ radical scavenging activities with the values of $197.56 \pm 4.43$ VCEAC $\mathrm{mg} / \mathrm{g}$ extract and $283.37 \pm 2.09$ TEAC mg $/ \mathrm{g}$ extract, respectively. $\mathrm{DPPH}$ and $\mathrm{ABTS}^{+}$radical scavenging activities of RA extract were 190.89 \pm 2.22 VCEC mg /g extract and $259.11 \pm$ $4.85 \mathrm{TEAC} \mathrm{mg} / \mathrm{g}$ extract, respectively. The other extracts, the VCEAC value was followed by RD, TwA, RM, TwD, TwM, BD, BM, LM, LD, and LA, the TEAC value was as follows: RD, TwA, TwD, LD, BD, TwM, BM, LM, RM and LA.

The $\mathrm{SC}_{50}$ values of nitric oxide and hydroxyl radical scavenging activities from BA extract were $113.18 \pm 14.63$ and
933.93 $\pm 9.15 \mu \mathrm{g} / \mathrm{mL}$, respectively and $\mathrm{RA}$ extract were $125.39 \pm 8.15$ and $978.44 \pm 9.02 \mu \mathrm{g} / \mathrm{mL}$, respectively. BA and RA extracts had more potent nitric oxide and hydroxyl radical scavenging activities than vitamin $\mathrm{C}$ but less than quercetin. For hydroxyl radical scavenging activity, BA and RA extracts were more potent than Trolox but less than gallic acid. For the other extracts, the rank of nitric oxide scavenging activity was TwA> $\mathrm{LD}>\mathrm{RM}>\mathrm{TwM}, \mathrm{BM}$ and TwD, whereas, LA, LM, RD and BD have $\mathrm{SC}_{50}$ with more than $1000 \mu \mathrm{g} / \mathrm{mL}$. The BA and RA extracts with high phytochemical contents and antioxidant activities values were subjected for the GC-MS analysis. A comparison of the mass spectra with Wiley9 library and the relative percentages as shown in Table 3 revealed that there were fatty acid derivatives which have been reported to be potential antioxidant (Ismail et al., 2010; Meechaona et al., 2007), anti-cardiovascular and antiinflammatory agents (Rustan and Drevon, 2005) in the BA and RA extracts. For the RA extracts, 7 fatty acid derivatives consisting of methyl palmitate, palmitic acid, methyl oleate, methyl stearate, linoleic acid, 9-octadecenoic acid and stearic acid, were found in the peak area range of $1.69-17.52 \%$. In the BA extracts, 2 phytosterols, stigmast-5-en-3-ol (3.99\%) andstigmastane-3,6-dione (7.15\%), 2 phenolic compounds, isovanillic acid (0.39\%) and 2,6dihydroxy-4-methoxybenzophenone $(0.71 \%), 5$ major fatty acid derivatives(1.68-12.46\%), palmitic acid, linoleic acid, ethyl linoleate, 9-octadecenoic acid and ethyl (Z)-9-octadecenoate were detected. Consequently, the observed antioxidant properties of $G$. schomburgkiana should be derived from the detected phytochemical contents and beneficial fatty acid of the extracts.

Table 2 Total phytochemical contents and antioxidant activities of 12 Ma-dan extracts.

\begin{tabular}{|c|c|c|c|c|c|c|c|}
\hline Extracts & Phenolic content & $\begin{array}{c}\text { Flavonoid } \\
\text { content }\end{array}$ & Xanthone content & $\begin{array}{c}\text { DPPH } \\
\text { scavenging }\end{array}$ & $\begin{array}{c}\text { ABTS+• } \\
\text { scavenging }\end{array}$ & $\begin{array}{l}\text { Nitric oxide } \\
\text { scavenging }\end{array}$ & $\begin{array}{l}\text { Hydroxyl radical } \\
\text { scavenging }\end{array}$ \\
\hline & $\begin{array}{c}\text { GAE } \\
(\mathrm{mg} / \mathrm{g} \text { extract }) 1\end{array}$ & $\begin{array}{c}\mathrm{QE} \\
(\mathrm{mg} / \mathrm{g} \text { extract)2 }\end{array}$ & $\begin{array}{c}\text { AME } \\
(\mathrm{mg} / \mathrm{g} \text { extract }) 3\end{array}$ & $\begin{array}{c}\text { VCEAC } \\
\text { (mg/g extract)4 }\end{array}$ & $\begin{array}{c}\text { TEAC } \\
(\mathrm{mg} / \mathrm{g} \text { extract }) 5\end{array}$ & $\begin{array}{c}\text { SC50 } \\
(\mu \mathrm{g} / \mathrm{mL})\end{array}$ & $\begin{array}{c}\mathrm{SC50} \\
(\mu \mathrm{g} / \mathrm{mL})\end{array}$ \\
\hline LD & $58.84 \pm 3.51 \mathrm{j}$ & $111.06 \pm 2.21 \mathrm{f}$ & $448.02 \pm 8.05 b$ & $93.93 \pm 2.43 \mathrm{~h}$ & $151.51 \pm 5.86 \mathrm{e}$ & $315.60 \pm 18.76 \mathrm{~d}$ & $>1,000$ \\
\hline LA & $37.68 \pm 1.81 \mathrm{k}$ & $92.68 \pm 3.51 \mathrm{~g}$ & $89.66 \pm 0.77 \mathrm{i}$ & $87.21 \pm 5.75 \mathrm{~h}$ & $31.21 \pm 6.47 \mathrm{j}$ & $>1,000$ & $>1,000$ \\
\hline LM & $97.97 \pm 2.66 \mathrm{i}$ & $44.55 \pm 1.18 \mathrm{i}$ & $131.16 \pm 1.17 \mathrm{~g}$ & $96.75 \pm 6.85 \mathrm{~g}, \mathrm{~h}$ & $93.19 \pm 3.56 \mathrm{~h}$ & $>1,000$ & $>1,000$ \\
\hline $\mathrm{RD}$ & $140.29 \pm 6.53 \mathrm{f}, \mathrm{g}$ & $219.47 \pm 26.97 \mathrm{c}$ & $324.39 \pm 8.40 \mathrm{e}$ & $168.17 \pm 2.65 b$ & $219.51 \pm 7.45 c$ & $>1,000$ & $>1,000$ \\
\hline RA & $427.83 \pm 4.84 \mathrm{a}$ & $626.32 \pm 59.97 \mathrm{a}$ & $625.80 \pm 3.78 \mathrm{a}$ & $190.89 \pm 2.22 \mathrm{a}$ & $259.11 \pm 4.85 b$ & $125.39 \pm 8.15 b$ & $978.44 \pm 9.02 b$ \\
\hline $\mathrm{RM}$ & $145.80 \pm 3.05 \mathrm{f}$ & $195.64 \pm 8.98 \mathrm{c}$ & $137.04 \pm 1.17 \mathrm{f}$ & $141.13 \pm 6.85 \mathrm{~d}$ & $85.64 \pm 2.65 \mathrm{i}$ & $392.93 \pm 11.95 \mathrm{e}$ & $>1,000$ \\
\hline TwD & $133.33 \pm 3.62 \mathrm{~g}$ & $145.79 \pm 0.81 \mathrm{e}$ & $338.44 \pm 6.38 \mathrm{~d}$ & $131.28 \pm 0.88 \mathrm{~d}$ & $174.34 \pm 8.21 \mathrm{~d}$ & $941.50 \pm 45.80 \mathrm{~h}$ & $>1,000$ \\
\hline TwA & $235.65 \pm 5.43 \mathrm{~d}$ & $205.30 \pm 7.27 \mathrm{c}$ & $357.85 \pm 0.77 \mathrm{c}$ & $150.98 \pm 3.31 \mathrm{c}$ & $187.44 \pm 12.91 \mathrm{~d}$ & $245.61 \pm 8.65 c$ & $>1,000$ \\
\hline TwM & $359.13 \pm 13.67 \mathrm{c}$ & $159.97 \pm 0.54 \mathrm{~d}$ & $115.71 \pm 2.76 \mathrm{~h}$ & $123.99 \pm 3.62 \mathrm{e}$ & $121.47 \pm 6.73 \mathrm{f}, \mathrm{g}$ & $688.07 \pm 28.12 \mathrm{f}$ & $>1,000$ \\
\hline BD & $103.77 \pm 5.59 \mathrm{~h}$ & $59.81 \pm 0.47 \mathrm{~h}$ & $144.96 \pm 5.10 \mathrm{f}$ & $114.72 \pm 2.21 \mathrm{f}$ & $131.95 \pm 8.35 \mathrm{f}$ & $>1,000$ & $>1,000$ \\
\hline BA & $390.15 \pm 7.89 b$ & $414.49 \pm 15.99 b$ & $615.07 \pm 9.97 \mathrm{a}$ & $197.56 \pm 4.43 \mathrm{a}$ & $283.37 \pm 2.09 \mathrm{a}$ & $113.18 \pm 14.63 b$ & $933.93 \pm 9.15 \mathrm{c}$ \\
\hline $\begin{array}{c}\text { BM } \\
\text { Vitamin } C^{*}\end{array}$ & $\begin{array}{c}160.58 \pm 2.51 \mathrm{e} \\
\mathrm{ND}\end{array}$ & $\begin{array}{c}156.23 \pm 4.54 \mathrm{~d} \\
\text { ND }\end{array}$ & $\begin{array}{c}147.13 \pm 7.46 f \\
\text { ND }\end{array}$ & $\begin{array}{c}104.56 \pm 3.76 \mathrm{~g} \\
\mathrm{ND}\end{array}$ & $\begin{array}{c}113.69 \pm 1.88 \mathrm{~g} \\
\mathrm{ND}\end{array}$ & $\begin{array}{c}625.50 \pm 77.59 \mathrm{f} \\
711.84 \pm 153.40 \mathrm{~g}\end{array}$ & $\begin{array}{l}>1,000 \\
\text { ND }\end{array}$ \\
\hline Trolox* & ND & ND & ND & ND & ND & ND & $>1,000$ \\
\hline Gallic acid* & ND & ND & ND & ND & ND & ND & $428.53 \pm 6.38 \mathrm{a}$ \\
\hline Quercetin* & ND & ND & ND & ND & ND & $202.41 \pm 5.38 \mathrm{a}$ & ND \\
\hline
\end{tabular}

Data are expressed as means \pm S.D., $\mathrm{n}=3, \mathrm{ND}$; Not detected.

Different letters $(\mathrm{a}-\mathrm{k})$ with in the same column indicate significant differences at $p<0.05$ by $\mathrm{t}$-test. The values are descending order as a $>\mathrm{k}$.

*; antioxidant standards.

$1 \mathrm{GAE}(\mathrm{mg} / \mathrm{g}$ extract); Gallic acid equivalent ( $\mathrm{mg}$ of gallic acid/g extract).

2QE (mg/g extract); Quercetin equivalent (mg of quercetin/g extract).

3AME (mg/g extract); $\alpha$-Mangostin equivalent (mg of $\alpha$-mangostin /g extract).

4VCEAC ( $\mathrm{mg} / \mathrm{g}$ extract); Vitamin C equivalent antioxidant capacity ( $\mathrm{mg}$ of vitamin $\mathrm{C} / \mathrm{g}$ extract).

5TEAC ( $\mathrm{mg} / \mathrm{g}$ extract); Trolox equivalent antioxidant capacity ( $\mathrm{mg}$ of Trolox/g extract). 
Table 3 The volatile compounds of BA and RA from GC-MS analysis.

\begin{tabular}{|c|c|c|c|c|c|}
\hline No. & Compound & $\begin{array}{c}\text { RT } \\
\text { (min) }\end{array}$ & $\begin{array}{c}\text { MW } \\
(\text { g.mol }\end{array}$ & $\begin{array}{c}\text { BA extract } \\
\text { (\% PA) }\end{array}$ & $\begin{array}{c}\text { RA extract } \\
\text { (\% PA) }\end{array}$ \\
\hline 1 & Mesity oxide & 15.52 & 98 & 0.86 & - \\
\hline 2 & Furfural & 6.80 & 96 & 0.77 & 0.32 \\
\hline 3 & Diacetone alcohol & 6.98 & 116 & 0.45 & 0.25 \\
\hline 4 & Furfuryl alcohol & 16.86 & 98 & 0.64 & - \\
\hline 5 & 2-Carboxylmethyl-3-n-hexyl-maleic acid anhydride & 26.85 & 240 & 0.31 & - \\
\hline 6 & Levoglucosan & 28.45 & 162 & 14.63 & 5.77 \\
\hline 7 & Isovanillic acid & 29.38 & 168 & 0.39 & - \\
\hline 8 & 5-acetyl barbituric acid & 31.47 & 170 & 2.36 & - \\
\hline 9 & Myristic acid & 33.23 & 228 & - & 0.14 \\
\hline 10 & Methyl palmitate & 36.50 & 270 & - & 15.53 \\
\hline 11 & Palmitic acid & 37.36 & 256 & 12.01 & 11.73 \\
\hline 12 & Ethyl palmitate & 37.80 & 284 & 1.83 & 0.17 \\
\hline 13 & Margaric acid & 39.20 & 270 & 0.59 & 0.36 \\
\hline 14 & Methyl linoleate & 39.71 & 294 & - & 0.21 \\
\hline 15 & Methyl oleate & 39.82 & 296 & - & 12.65 \\
\hline 16 & Methyl octadec-8-enoate & 39.92 & 296 & - & 0.48 \\
\hline 17 & Methyl stearate & 40.28 & 298 & - & 2.74 \\
\hline 18 & Linoleic acid & 40.57 & 280 & 6.03 & 5.11 \\
\hline 19 & Oleic acid & 40.67 & 282 & 12.46 & 17.54 \\
\hline 20 & Ethyl linoleate & 40.91 & 308 & 1.68 & - \\
\hline 21 & Ethyl (Z)-9-Octadecenoate & 41.02 & 310 & 3.39 & - \\
\hline 22 & Stearic acid & 41.05 & 284 & - & 1.69 \\
\hline 23 & Ethyl stearate & 41.47 & 312 & 0.33 & - \\
\hline 24 & Methyl (E,E)-6,9-octadecadienoate & 41.48 & 294 & - & 0.49 \\
\hline 25 & 2,6-Dihydroxy-4-methoxybenzophenone & 42.46 & 244 & 0.71 & - \\
\hline 26 & Methyl arachidonate & 43.76 & 326 & - & 0.26 \\
\hline 27 & Stigmast-5-en-3-ol & 50.96 & 414 & 3.99 & - \\
\hline 28 & Stigmastane-3,6-dione & 52.82 & 428 & 7.15 & - \\
\hline
\end{tabular}

\%PA: Percent Peak area; - : Not appeared; MW: Molecular weight; RT: Retention time.

\section{CONCLUSION}

The RA and BA extracts of Garcinia schomburgkiana revealed high phenolic, flavonoid and xanthone contents, and exhibited beneficial fatty acids. They possessed more promising antioxidant capacities and radical scavenging activities than vitamin $\mathrm{C}$ and Trolox. Thus, such highly active antioxidant compounds would be interesting areas for further phytochemical investigation and nutraceutical promotion as a possible antioxidant source.

\section{ACKNOWLEDGMENTS}

This research is supported by grant funds under the program Strategic Scholarships Fellowships Frontier Research Networks (Specific for Southern region) for the Ph.D. Program Thai Doctoral degree from Office of the Higher Education Commission, Thailand. The financial was supported by Walailak University Fund. Facility and technical assistance from the Utilization of Natural Products Research Unit, Walailak University, are also acknowledged.

\section{REFERENCES}

Ahmed RG. Is there a balance between oxidative stress and antioxidant defense system during development? MJIAS, 2005;15: 55-63.

Aisha AFA, Abu-Salah KM, Ismail Z, Abdul-Majid AMS. Determination of total xanthones in Garciniamangostana fruit rind extracts by ultraviolet (UV) spectrophotometry. J Med Plants Res, 2013; 7 : 29-35.
Elya B, Katrin, Mun'Im A, Hasiholan A, Marlin I, Mailandari M. Antioxidant activities of leaves extracts of three species of Garcinia. IJMAP, 2012; 2: 691-693.

Fun HK, Koysomboon S, Chantrapromma K, Chantrapromma S. A cocrystal of clusiacitran A, clusiacitran B, fluorinated clusiacitran A and fluorinated clusiacitran B (0.45:0.45:0.05:0.05). Acta Crystallogr E, 2006; E62: O3228-O3230.

Gontijo VS, de Souza TC, Rosa IA,Soares MG, da Silva MA, Vilegas W, Júnior CV,dos Santos MH. Isolation and evaluation of the antioxidant activity of phenolic constituents of the Garcinia brasiliensis epicarp. Food Chem, 2012; 132: 1230-1235.

Gutierrez-Orozco F,Failla ML.Biological activities and bioavailability of mangosteenxanthones: A critical review of the current evidence. Nutrients, 2013; 5: 3163-3183.

Harput UŞ, Genç Y, Khan N,Saracoglu İ. Radical Scavenging Effects of Different Veronica Species. Rec Nat Prod,2011; 5: 100-107.

Ho SC, Tang YL, Lin SM,Liew YF. Evaluation of peroxynitrite-scavenging capacities of several commonly used fresh spices. Food Chem,2010; 119: 1102-1107.

Häfner A,Frahm AW.Biflavanoids from the Heartwood of Garcinia schomburgkiana and their structural elucidation as atropisomers. Planta Med,1993; 59: A604.

Ismail M, Mariod A, Bagalkotkar G,Ling HS. Fatty acid composition and antioxidant activity of oils from two cultivars of Cantaloupe extracted by supercritical fluid extraction. Grasas y Aceites, 2010; 61: 37-44.

Jung HA, Su BN, Keller WJ, Mehta RG,Kinghorn AD.Antioxidant xanthones from the pericarp of Garciniamangostana (mangosteen).J Arg Food Chem,2006; 54: 2077-2082.

Kondo M, Zhang L, Ji H, KouY,Ou B. Bioavailability and antioxidant effects of a xanthone-rich mangosteen (Garciniamangostana) Product in Humans. J Arg Food Chem, 2009; 57: 8788-8792.

Kosema N, Han YH, Moongkarndia, P. Antioxidant and Cytoprotective activities of methanolic extract from Garcinia mangostana Hulls. ScienceAsia, 2004; 33: 283-292. 
KhansariN,ShakibaY,MahmoudiM.Chronic inflammation and oxidative stress as a major cause of age-related diseases and cancer. Recent Pat Inflamm Allergy Drug Discov,2009; 3:73-80.

Leopoldini M, Russo N,Toscano M. The molecular basis of working mechanism of natural polyphenolic antioxidants.Food Chem, 2011; 125: 288-306.

Lim TK.2012. Edible Medicinal and Non-Medicinal plants. Volume 2, Springer Dordrecht Heidelberg London: New York, USA,pp. 123-124.

Limón-Pacheco J,Gonsebatt ME. The role of antioxidants and antioxidant-related enzymes in protective responses to environmentally induced oxidative stress. Mutat Res-Gen Tox En, 2009; 674: 137-147.

Meechaona R, Sengpracha W, Banditpuritat J, Kawaree R,Phutdhawong W. Fatty acid contents and antioxidant activity of Thai banabas. MaejoInt J Sci Tech,2007; 1: 222-228.

Merza J, Aumond MC, Rondeau D,DumontetV, Ray AML, Se'raphin D,RichommeP.Prenylatedxanthones and tocotrienols from Garciniavirgata. Phytochemistry,2004; 65: 2915-2920.

MungmeeC, Sitthigool S, Buakeaw A,Suttisri R. A new biphenyl and other constituents from the wood of Garcinia schomburgkiana.Nat Prod Res,2013; 27: 1949-1955.

Nanasombat S, Khanha K, Phan-im J, Jitaied J, Wannasomboon S, Patradisakorn S, Wongsil A.Antimicrobial and antioxidant activities of Thai local fruit extracts: application of a selected fruit extract Phyllanthus emblicaLinn as a natural preservative in raw ground pork during refrigerated storage.TOJSAT, 2012; $2: 1-7$.

Nargis J, Melati K, Lai CS, Hasnah O, Wong KC, Vikneswaran M,Khaw KY, Antioxidant, anti-cholinesterase and antibacterial activities of the bark extracts of Garciniahombroniana. Afr J Pharm Pharmaco, 2013; 7: 454-459.

Omwamba M, Li F, Sun G,Hu Q. Antioxidant effect of roasted barley (Hordeumvulgare L.) grain extract towards oxidative stress in vitro and in vivo. FNS,2013; 4: 139-146.

Panyathepa A, Chewonarina T,Taneyhillb K, Vinitketkumnuen U. Antioxidant and anti-matrix metalloproteinases activities of dried longan (Euphoria longana) seed extract. ScienceAsia, 2013; 39: 12-18.

Pedraza-Chaverri J, Cárdenas-Rodríguez N, Orozco-Ibarra M,Pérez-Rojas JM.Medicinal properties of mangosteen (Garciniamangostana). Food ChemToxicol,2008; 46: 3227-3239.

PoljšakB,FinkR. The Protective Role of antioxidants in the defence against ROS/RNS-mediated environmental pollution. Oxid Med Cell Longev, 2014; 2014:1-22.

Pothitirat W,Gritsanapan W. Quantitative Analysis of total mangostins in Garciniamangostanafruit rind. J Health Res, 2008; 22: 161166.

Ratnam DV,Ankola DD, Bhardwaj V, Sahana DK, Kumar MN. Role of antioxidants in prophylaxis and therapy: A pharmaceutical perspective. J Control Release,2006; 113: 189-207.
Re R,Pellegrini N, Proteggente A,Pannala A, Yang M,RiceEvans C. Antioxidant activity applying an improved ABTS radical cationdecolorization assay. Free Radical Bio Med,1999; 26: 1231-1237.

Arild CRustanand Christian A Drevon. 2005. Fatty Acids: Structures and Properties. [ONLINE] Available at: https://www.uio.no/studier/emner/matnat/farmasi/FRM2041/v06/undervis ningsmateriale/fatty_acids.pdf. [Accessed 08 May 2015].

SenS,Chakraborty R, SridharC, Reddy YSR,De B. Free radical, antioxidants, diseases and phytomedicines: current status and future prospect. Int J Pharm Sci Rev Res, 2010; 3: 91-100.

Subhashini N,Nagarajan G,Kavimani S.In vitro antioxidant and anticholinesterase activities of Garcinia combogia. Int $\mathrm{J}$ Pharm PharmSci,2011; 3: 129-132.

Sudha G, Priya MS, Shree R,Vadivukkarasi S. In vitro free radical scavenging activity of raw pepino fruit (SolanummuricatumAiton).IJCPR, 2011; 3: 137-140.

Tang YP, Li PG, Kondo M, Ji HP, Kou Y,Ou B. Effect of a mangosteendietary supplement on human immune function: A randomized, double-blind, placebo-controlled trial. J Med Food,2009; 12: 755-763

Tavasalkar SU, Mishra HN,Madhavan S. Evaluation of antioxidant efficacy of natural plant extracts against synthetic antioxidants in sunflower oil. JFPT,2012; 1: 1-5.

Vo HT, Nguyen NTT, Nguyen HT, DoKQ, Connolly JD, Maas G, Heilmann J, Werz UR, Pham HD,Nguyen LHD. Cytotoxic tetraoxygenatedxanthones from the bark of Garcinia schomburgkiana. PhytochemLett, 2012; 5: 553-557.

Wetwitayaklung $\mathrm{P}$, Charoenteeraboon J, Limmatvapirat C,Phaechamud T.Antioxidant activities of some Thai and exotic fruits cultivated in Thailand. RJPBCS,2012; 3: 12-21.

Yu L, Zhao M, Yang B, Zhao Q,Jiang Y. Phenolics from hull of Garciniamangostana fruit and their antioxidant activities.Food Chem,2007; 104: 176-181.

Zongo C, Savadogo A, Ouattara L, Bassole IHN, Ouattara CAT, Ouattara AS, BarroN, Koudou J,Traore AS. Polyphenols Content, Antioxidant and antimicrobial activities of Ampelocissusgrantii (Baker) Planch. (Vitaceae): A medicinal plant from Burkina Faso. Int J Pharmacol, 2010; 6: 880-887.

\section{How to cite this article:}

Meechai I, Phupong W, Chunglok W, Meepowpan P. Antioxidant Properties and Phytochemical Contents of Garcinia schomburgkiana Pierre. J App Pharm Sci, 2016; 6 (06): 102-107. 